\title{
マイクアレイのメインローブモデルを用いた点音源検出手法
}

\author{
佐々木 洋 子*1*2 加賀美 聡 $* 1 * 2$ 溝 口 博 $* 1 * 2$
}

\section{Point Sound Source Detection using the Main-Lobe Model of a Microphone Array}

\author{
Yoko Sasaki $^{* 1 * 2}$, Satoshi Kagami*1*2 and Hiroshi Mizoguchi*1*2
}

\begin{abstract}
This paper proposes a sound source localization method which is robust for multiple sound sources and sound pressure difference. We propose the Main-Lobe Fitting algorithm using the directional pattern of a microphone array to reduce localization error in reverberant environments and noisy conditions such as a robot moving. The localization method is a post process of beam forming and it filters out reflected or interfered signals by selecting spectra which are fitted with the main-lobe model. We implemented the method on our 32ch microphone array mounted on a mobile robot, and evaluated the performance in different conditions. The experimental results show that the system provides accurate and robust sound localization for multiple different sound sources during robot motion.
\end{abstract}

Key Words: Microphone Array, Beam Forming, Sound Source Localization, Point Source Detection, Main-lobe Model

1. は じめに

近年 , ロボットに搭載した複数のマイクにより，周囲の音源 位置を推定する音源定位や，混合音から目的音を分離する音源 分離の研究が多数報告されている [1]. 実環境下でロボットが周 囲の音源を定位 ·分離する機能は, 音声認識や環境変化の初期知 覚に役立つ.この中で音源定位は, ロボットが注意を向ける方 向を選択したり，呼びかけや物音に気づいて動作を変更するな ど , 人のいる環境下でロボットが安全に行動するための重要な 要素技術である . また定位情報は音源分離や分離音の認識にも 役立つ. 移動ロボットか環境音を理解するためには, 同時に複 数の音源を扱えること, 音源ごとの音圧差や距離差に対応して 広い範囲を扱えること，反射や干渉を受けた音に対処すること か望まれる . 例えば家庭などの屋内を想定すると，周囲 $10[\mathrm{~m}]$ 前後の音までとらえられれば有用である．

しかし音は環境変化の影響を受けやすく, 音源数の増加や, 音 源までの距離が長い場合，また反射や残響のある環境において， 音源定位の性能は大きく低下する . 特に移動ロボットでは, 音 源とマイクとの距離は刻々と変化し, 音源ごとの音圧変化や口 ボット自身からの雑音等, 非定常な要素が多い. 音源自体も時 間方向の変化が大きい信号である . 広範囲を動く移動ロボット 八適用するためには, 変化する環境条件下で広範囲の音を扱う

\footnotetext{
原稿受付 2007 年 12 月 14 日

${ }^{* 1}$ 東京理科大学理工学研究科

$* 2$ 産業技術総合研究所デジタルヒューマン研究センター

${ }^{* 1}$ Tokyo University of Science

${ }^{* 2}$ Digital Human Research Center, AIST

口本論文は学術性で評価されました .
}

ことが大きな課題である .

これまでに，音声認識を目的としてロボットに装着したマイ クによる音源定位システムが多数提案されているが, この問題 を明示的に扱った研究例は報告されていない，従来手法として， 人間の耳と同樣に 2 本のマイクを用いた両耳聴の研究があるが， 複数音源の定位や, 動きながら認識に必要な分離性能を得るの はまた難しい . 一方で害用性の観点から素子数を増やしたマイク アレイのロボットへの実装例 [2]〜 [4] が多数報告されている . 代 表的な音源定位手法として, 遅延和ビームフォーミング (Delay and Sum Beam Forming, DSBF) [5] は計算が単純で多く採 用されている.ただし定位性能の向上には多数のマイクを必要 とし, 高精度な定位性能が得にくい，といった弱点がある [6] . 適応型ビームフォーマの一つである MUSIC (MUltiple SIgnal Classification) [7] は, 固有值展開を多用しており計算量が多い 一方で, 比較的少数の素子で高精度な音源定位が可能であり注 目されている手法である [8] [9] .

DSBF や MUSIC をはじめとする数十 $[\mathrm{ms}]$ ごとの各瞬間で の音源定位技術とともに, 過去の定位履歴から定位のあいまい 性を補い, 音源を追跡する手法力提案されている.動的環境下 での音源定位について, Valin らは, 8 チャンネルのマイクア レイを用いて移動ロボットによる複数音源の定位, 移動音の追 跡 [10] を実現している . パーティクルフィルタによる音源追跡 から各瞬間に生じる誤検出を除外しているが, 音源間の音圧差 (距離差) や音源数の増加については述へてていい，また事前に 部屋内の各位置で観測した音源定位結果を蓄積した静的な雑音 源の分布を用いることで, 移動ロボットが対象音源をとらえや すい場所を選択する方法 [11] なども報告されている . 
別のアプローチとして, カメラやレーザ距離センサなど, 、 イク以外のセンサとの情報統合による研究例がある. カメラに よる顔追跡を利用した話者定位 [12]や , パーティクルフィルタ を用いて視覚情報と音情報を統合した音源追跡 [13]などか報告 されている．これらは視覚情報を併用することで音情報のあい まい性を解消している．また中臺ら [14] は，ロボット搭載型マ イクアレイと環境に配置したマイクアレイを統合することで， 音源までの距離増加に伴うあいまい性を解消している .

ロボットの音源検出機能を向上させるためには, 上述のよう に音源定位の後段処理によって頑健性を高めるアプローチとと もに, 各瞬間での音源定位性能を向上させることが重要である . 筆者らはこれまでに, DSBF の性能を向上させる，低サイド ローブ配置マイクアレイを開発し, DSBF の後に周波数帯域選 択 (Frequency Band Selection, FBS) を用いた複数音源の検 出機能を構筑してきた $[15]$.この手法では, 反射の影響は小さ く直接音が最も強いこと, また音源ごとの周波数成分は独立で あることを仮定していた . この仮定のため音源数か増えるにつ れて精度が低下する．また指向性に幅を持つビームフォーミン グでは, 反射によるピークが実際より大きく観測され，また近 接した音源の影響でピークシフトが生じる可能性があり，環境 中の反射や他音源の干渉を考慮することが大きな課題であった．

乥こで，これらの問題点へ対処するために点音源に対するマ イクアレイのメインローブモデルを定義し , ビームフォーミン グの後段処理として周波数ごとにメインローブモデルとの適合 判定 (Main-Lobe Fitting, MLF) を行う手法を提案する . 提 案手法は, ビームフォーミングで得られる空間スペクトルから 点音源と判定された周波数成分のみを抽出して定位を行うこと で, 実環境下でのより頑健な音源定位を実現する．反射や残響 の影響を低減させるという目的に対しては，Griffith-Jim 型適 応アレイに代表される適応型ビームフォーミング $[16]$ や , サイ ドローブ最小ビームフォーミング $[17]$ など，観測信号に基づき フィルタの特性を適応的に更新する手法があげられる．一方提 案法は, 、イクの幾何配置から得られるモデルのみを使用する ため, 移動ロボットのような刻々と環境条件か变化する環境下 での有用性が期待できる .

\section{2. メインローブモデルを用いた音源定位手法}

本章では，DSBF で得られる点音源に対する感度分布を定義 し $(2.1 ， 2.2$ 節 $)$, メインローブ部分をモデルとした点音源の抽 出手法について述べる．まずDSBF およびメインローブモデル の算出を定義し $(2.1,2.2$ 節) , 単一周波数でのメインローブ の適合判定方法を説明する (2.3 節) . 次に一般の音源に対する メインローブモデルを用いた音源定位法について説明する (2.4 節) . 以下では, サイドローブはメインローブと比較して十分小 さく，メインローブの両端に極小值があると仮定する．低サイ ドローブマイクアレイの実現可能性については次章で述べる．

\section{1 遅延和ビームフォーミング（ DSBF）}

各チャンネルの信号出力が同位相となるように, 入力信号に 遅延を与えて加算することで目的方向 (以下, 焦点) の音を強 調させる . Fig. 1 のように, 空間中においたマイクアレイの中 心を原点として焦点 $C$ の座標を $(r, \theta, \phi)$ と極座標で表すと， $i$

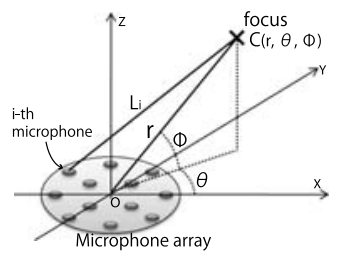

Fig. 1 DSBF on spherical coordinate system

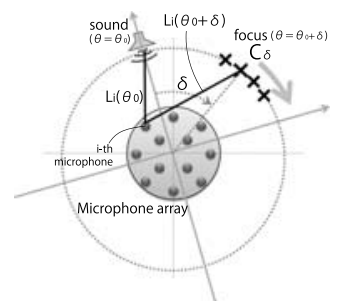

(a) Scanning the focus

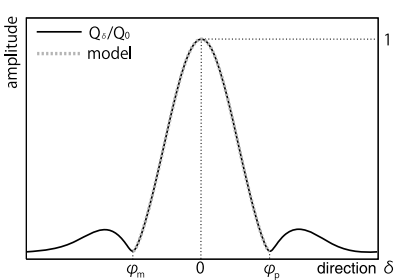

(b) Spatial spectrum
Fig. 2 Spatial spectrum and main-lobe model

番目のマイクに与える遅延 $\tau_{i}(r, \theta, \phi)$ は式 (1) となる.

$$
\tau_{i}(r, \theta, \phi)=\frac{r-L_{i}(r, \theta, \phi)}{V_{s}}
$$

ただし， $V_{s}$ は音速， $L_{i}$ は焦点から $i$ 番目のマイク $(i=$ $1,2, \cdots, M)$ までの距離を表す . また , 音の伝播モデルは球面 波とする $i$ 番目のマイクへの時刻 $t$ の入力信号を $x_{i}(t)$ とす ると, 素子数 $M$ のマイクアレイで得られる焦点 $C$ への DSBF 出力 $s_{c}(t)$ は次式で表される.

$$
s_{c}(t)=\frac{1}{M} \sum_{i=1}^{M} x_{i}\left(t+\tau_{i}\right)
$$

2.2 点音源に対する DSBF 時のメインローブモデル 空間内て焦点 $C$ をスキャンさせることで, 音の感度分布を示 す空間スペクトルが得られる . 本稿では, マイクアレイ中心か らの距離 $r$ および仰角 $\phi$ は固定值とし, 方位角 $\theta$ のみの音源 定位を行う $r$ に関しては, アレイ直径より十分大きな円周上 の点に焦点をとる . スキャンさせる円周の半径は, 音源距離に よる空間スペクトルの形状変化が小さく, 遠方音場と近似でき る距離 [18] とする .ここで近接音場とみなせる範囲内では焦点 をスキャンさせる円周の径によって空間スペクトルの形状が異 なるため, 複数の同心円上に焦点をスキャンさせることで音源 の距離を推定可能である .

$r$ と $\phi$ を固定したため, これ以降式 (1) の遅延を $\tau_{i}(\theta)$, 焦 点一マイク間距離を $L_{i}(\theta)$ と表す . Fig. 2 (a) に本稿での焦点ス キャンの模式図を示す.ここで $\theta=\theta_{0}$ においた一つの点音源 を考え，この音源の時刻 $t$ での信号を $y(t)$ とおくと $i$ 番目の マイク入力は $x_{i}(t)=y\left(t-L_{i}\left(\theta_{0}\right) / V_{s}\right)$ となる . また , スキャ ンさせる焦点を音源からの離角 (音源方向と焦点方向のなす角) $\delta\left(=\theta-\theta_{0}\right)$ の関数と考え, $C_{\delta}$ とおくと, 式 $(2)$ より焦点 $C_{\delta}$ で観測される DSBF 出力 $q_{\delta}(t)$ は式 $(3)$ で表される.

$$
q_{\delta}(t)=\frac{1}{M} \sum_{i=1}^{M} y\left(t+\tau_{i}\left(\theta_{0}-\delta\right)-\frac{L_{i}\left(\theta_{0}\right)}{V_{s}}\right)
$$

ただし , メインローブの形状が音源方向によって異なる場合は 
$q_{\delta}(t)$ は $\delta$ および $\theta$ の関数になる .ここで $q_{\delta}(t)$ の短区間フーリ 工変換から得られる振幅スペクトルを $Q_{\delta}(\omega)$ とすると, $Q_{\delta}(\omega)$ は点音源に対して得られる周波数 $\omega$ での空間スペクトルを示 す† . 観測される空間スペクトルのピーク形状はマイクアレイ の指向特性により決まる . 本稿では $\theta$ によらず指向特性が等し いと仮定し, 式 (4) でメインローブモデルを定義する.焦点ス キャンの方位により指向特性が異なる場合 model は $\omega, \delta, \theta$ の関数になる.

$$
\operatorname{model}(\omega, \delta)=\frac{Q_{\delta}(\omega)}{Q_{0}(\omega)} \quad\left(\varphi_{m}<\delta<\varphi_{p}\right)
$$

ただし $\varphi_{m}, \varphi_{p}$ は，Fig. $2(\mathrm{~b})$ に図示したようにメインローブ モデルの両端を示し, 弚れ光れ $\delta<0,0<\delta$ の範囲て対象音源 方向に最も近い空間スペクトルの極小值をとる角度とする . 本 稿では $\left(\varphi_{p}-\varphi_{m}\right)$ をメインローブ幅岵と定義する。

Fig. 2 (b) にメインローブモデルの模式图を示す . 横軸が音源 からの離角，縦軸が振幅スペクトルとなっており，メインロー ブモデル $\operatorname{model}(\omega, \delta)$ は対象音源からの離角と振幅スペクトル の減衰割合の関係を表す．

2.3 メインローブモデル適合判定 ( Main-Lobe Fitting, MLF)

観測された空間スペクトルのピークに対し，式 (4) で求めた メインローブモデルを当てはめ，適合度の判定を行う．

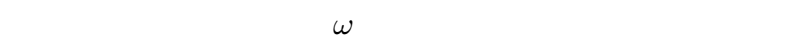
源の番号をマイクアレイに到達する音圧が大きい順に $n(n=$ $0,1,2, \cdots)$ とし $(n+1$ が音源数 $)$, 観測された空間スペクトルを $P(\omega, \theta)$ とする. $P(\omega, \theta)$ の極大值を大きい順にとり, 0 番目の音 源方向 $\theta=\theta_{0}$ のスペクトルを $P_{0}$ とおくと, $P_{0}$ は対象音源の振 幅スペクトル $S_{0}(\omega)$ と他音源からの漏洩 $l_{n}(\omega)(n=1,2, \cdots)$, および背景雑音 $B N(\omega)$ の和として，式 (5) で表される.

$$
P_{0}(\omega)=S_{0}(\omega)+\left\{l_{1}(\omega)+l_{2}(\omega)+\cdots\right\}+B N(\omega)
$$

また，対象音源のスペクトル $S_{0}(\omega)$ を用いて，空間スペクトル 中の対象音源成分 $E_{0}(\omega, \theta)$ は式 $(6)$ と表現できる.

$E_{0}(\omega, \theta)= \begin{cases}\operatorname{model}\left(\omega, \theta-\theta_{0}\right) S_{0}(\omega) & \text { if } \varphi_{m} \leq \theta-\theta_{0} \leq \varphi_{p} \\ 0 & \text { otherwise }\end{cases}$

ここで $S_{0}$ は一意に求まらないため，観測された空間スペク トルに対し $S_{0}$ を変化させて以下の方法で観測值に最も近い推 定スペクトル $E_{0}(\omega, \theta)$ を決定する . このとき $\left(P_{0}-S_{0}\right)$ は他音 源からの漏洩と背景雑音の和であるため, この值が対象として いるメインローブ部分外の空間スペクトルより大きくなること はない. 乥こで, $\left(P_{0}-E_{0}\right)$ が $\left(\theta-\theta_{0}\right)<\varphi_{m}, \varphi_{p}<\left(\theta-\theta_{0}\right)$ の範囲での $P(\theta)$ の最大値を上回る場合は, 以下に示す適合判 定の指標値によらず不適合とする .

観測された空間スペクトルから対象音源の推定スペクトル $E_{0}(\omega, \theta)$ を減算し，メインローブモデルとの適合判定を行う. $\theta_{0}$ 方向の音源成分を減算した空間スペクトル $A_{0}(\omega, \theta)$ は, 式
(7) で表される

$$
A_{0}(\omega, \theta)=P(\omega, \theta)-E_{0}(\omega, \theta)
$$

式 (5)〜 (7) の関係を Fig. 3 に図示する

減算後のスペクトルに対し，最小二乗法で $A_{0}\left(\omega, \theta_{0}\right)$ を通る 直線 $F_{0}(\omega, \theta)$ を求め, メインローブ幅内でこの直線との残差 (絶対誤差の平均) を用いてモデル適合の判定を行う . ここで， 残差が閾値を上回りモデルと不適合と判断されたピークを除外 し, 以降, 定位計算には用いない, モデルに適合した場合は, 次 のピークに対して同樣にモデルの適合判定を行う. 閾值を $R_{t h}$ として，モデル適合の判定式を次式に表す．

$$
\frac{1}{k} \sum_{\left(\theta-\theta_{0}\right)=\varphi_{m}}^{\varphi_{p}}\left|A_{0}(\omega, \theta)-F_{0}(\omega, \theta)\right|<R_{t h} P_{0}(\omega)
$$

ここで $k$ は角度 $\varphi_{m} \leq\left(\theta-\theta_{0}\right) \leq \varphi_{p}$ 間の焦点数を示す. また $R_{t h}$ は空間スペクトルの最大ピークに対する残差の割合 $\left(0<R_{t h}<1\right)$ を表す . Fig. 4 に MLF の模式図を示す .

観測された空間スペクトルに対し，最大ピークから MLF を 行い, 適合した場合は空間スペクトルからモデル分を減算し，次 のピークに対し同樣に適合判定を行う . ある周波数 $\omega$ の空間ス ペクトルに対する処理の流れを以下にまとめる .

Main-lobe Fitting Procedure

(1) 最大ピーク $P_{0}$ となる方向の音源成分 $E_{0}$ を推定

for $(j=1: J)\{$

$$
S_{0}=(1-j / J) P_{0}
$$

$E_{0}$ を計算 $\rightarrow$ 対象音減算後のスペクトル $A_{0}$ を計算

$A_{0}$ と直線との残差 $F_{0}$ を計算 $\}$ (ただし $J$ はループ回数) 残差最小となる $E_{0}$ を決定する .

(2) 推定スペクトル $E_{0}$ の適合判定

if $\left(P_{0}-E_{0}\right.$ がメインローブ部外の空間スペクトルより大きい，

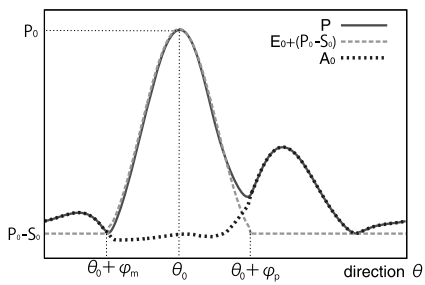

Fig. 3 Observed spatial spectrum and estimated main-lobe

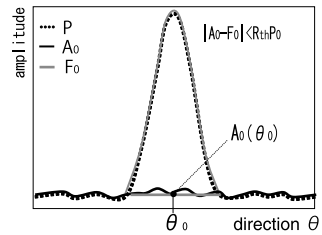

(a) Fit to the model

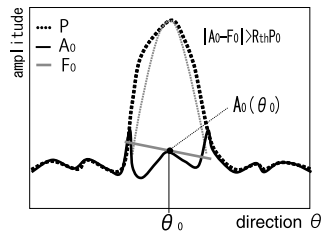

(b) Error fitting
Fig. 4 Judgment of main-lobe fitting

\footnotetext{
†ここでは $Q_{\delta}(\omega)$ を振幅スペクトルとしたが , パワースペクトルを用い てもよい，光の場合以降のスペクトルの次元もすべてパワースペクトル の次元となる
}

†十一般的に用いる焦点利得値から, 利得が半分になる角度の幅とは異なる。 


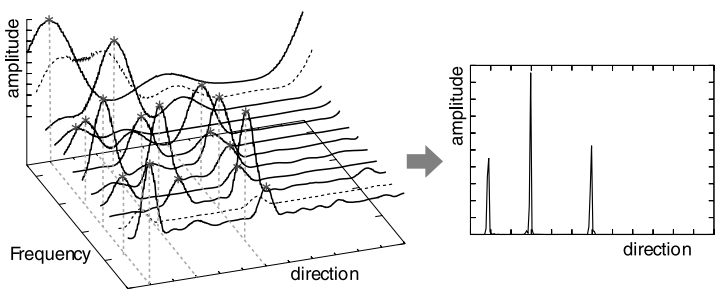

Fig. 5 Directional localization process by MLF

または (1) で求めた残差が閾値より大きい)

不適合 $\Rightarrow$ end

else モデルに適合

減算後の空間スペクトル $A_{0}$ に対し (1) の処理へ戻る (次のピーク $P_{1}$ となる方向の音源成分 $E_{1}$ を推定)

\section{$2.4 \mathrm{MLF}$ を用いた音源定位}

MLF により抽出された各周波数でのピークパワーを用いて音 源方向を決定する .このとき扱う周波数の分解能はハードウェ アのサンプリング周波数およびフーリエ変換に用いるデータ長 に依存する . 本手法は任意の分解能に適用可能であり, 分解能 が高いほど複数音源を同時に定位する効果が期待できるが, 光 の分高い計算コストが必要になる . 定位計算の流れを以下にま とめる . また Fig. 5 に音源定位の模式図を示す .

MLF Based Sound Localization Procedure

(1) DSBF で周波数ごとの空間スペクトルを計算

(2) 各周波数の空間スペクトルから MLF でモデル適合ピーク を抽出

(3) 抽出されたピークパワーの総和から音源定位

Fig. 5 左図は DSBF により得られる空間スペクトルの例であ り, 点線はモデルに適合するピークがない周波数成分，実線は 適合するピークを持つ周波数成分を示している.Fig. 5 右図に 示したモデルに適合したピークのピークパワー (Fig. 5 左図 * 点) の総和に対し，ピーク数およびピーク位置が光れどれ，推 定された音源数および音源方向となる.MLF で信頼度の高い ピークのみを抽出することで, 近接した複数音源に対して音源 間に生じる偽ピークや，ピークが乱れた反射成分を除外し，高 反射, 高残響下での音源定位における誤検出を低減させる . ま た音圧差のある音源に対する検出率の向上が期待できる .

\section{3. 低サイドローブマイクアレイ}

提案手法を直径 $330[\mathrm{~mm}]$ の 32ch マイクアレイ [19] に実装 した . 車輪型ロボットに搭載したマイクアレイおよびマイク配 置を Fig. 6 に示す . 16 [bit] , 16 [kHz] サンプリングで $32 \mathrm{ch}$ 同 期したデータを取得可能である . 4 章以降の実験では，すべて 16 [bit] , 16 [kHz] サンプリングで $32 \mathrm{ch}$ すべてのデータを用い る.ただし , MUSIC の一部については比較のために最外周の $8 \mathrm{ch}$ のみを用いた音源定位も行った .

またシミュレーションおよび実測したDSBF 時の指向特性を Fig. 7 に示す . Fig. 7 (a) のビームフォーミングシミュレーショ ンから求めた特性に対し, Fig. 7 (b) の実測した特性は $-20[\mathrm{~dB}]$ 以上ではよく一致している . $-20[\mathrm{~dB}]$ 以下での差は , ハードウェ アの離散化によるもの, および残響等の影響であると考えられ

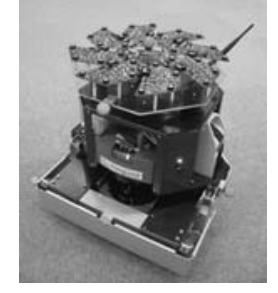

(a) Mobile robot with the array

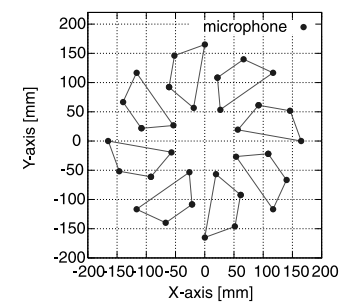

Fig. 6 Mobile robot with microphone array

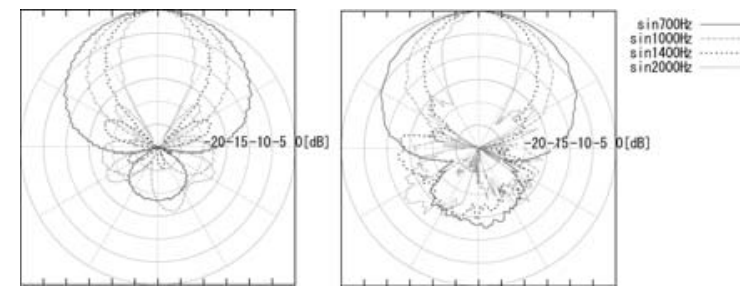

Fig. 7 Directional pattern of simulation (left) and experimental measurement (right)

る.以下の実験では, シミュレーションから求めた,$-20[\mathrm{~dB}]$ 以上のメインローブ部分をモデルとして採用する . 周波数ごと に , サイドローブの最大ゲインまで MLF によるピーク判定を 行う. 光のため, マイクアレイの特性によって, 扱い可能な雑 音に対する音圧差は異なる . 任意の配置のマイクアレイについ ては , 観測可能なメインローブゲインまでをモデルとすること でMLF を適用可能である .

\section{MLF 基礎実験}

構築したシステムを用いて, 音源定位の評価実験を行った . 以 下の実験では, 一回の計算に用いるデータ長を 2,048 点（空間 スペクトルの周波数分解能 $7.8[\mathrm{~Hz}])$ とし, $800 \sim 3,000[\mathrm{~Hz}]$ の 範囲でシミュレーションから作成したメインローブモデルを用 いて , メインローブモデルの適合判定を行った .

$4.2,4.3$ 節の音源定位評価においては, MUSIC [7] および FBS [15] を用いて比較を行った。弚れぞれ MLF と同樣に,800〜 $3,000[\mathrm{~Hz}]$ で事前にバンドパスフィルタをかけた信号を用い, こ の周波数帯での平均スペクトルから定位計算を行った . MUSIC では伝達関数および音源数の情報が必要であるが, 本実験では 伝達関数としてマイクの幾何配置から計算した値を採用し, 音 源数は樣々な推定手法が提案されているが, 本稿では真值を与 えて計算した。

4.1 判定閾值と適合ピーク数

まず MLF の適合判定に用いる閾値 $R_{t h}$ の設定範囲と抽出 ピークの関係を示す $. R_{t h}=0.03,0.09,0.14,0.20$ とした場 合の, 音源の持つ周波数成分に対する適合ピーク数の割合お よび，適合ピーク方向の音源からの角度差を光れ光れ求めた . 実験は無響室および, 残響時間 $\left(R T_{20}\right) 150[\mathrm{~ms}]$, 騒音レベル $\left(L_{A}\right) 35[\mathrm{~dB}]$ の部屋 A の 2 箇所で行った · 音源はスピーカ (YAMAHA MS101II) から出力した男声，女声単独の場合と， 両方を 135 [deg] 間隔で同時に聞かせた場合の計 3 種類，距離

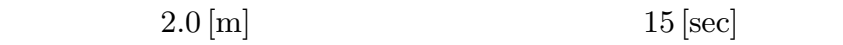


Table 1 Results of anechoic room

\begin{tabular}{|c||ccc|ccc|}
\hline \multicolumn{1}{||||||||c|c|c|c|c|}{} & \multicolumn{3}{c|}{ detected peak ratio [\%] } & \multicolumn{3}{c|}{ direction error[deg] } \\
\hline$R_{t h}$ & female & male & both & female & male & both \\
\hline \hline 0.03 & 76.2 & 72.7 & 66.0 & 2.7 & 1.1 & 2.3 \\
\hline 0.09 & 79.8 & 86.9 & 77.3 & 4.0 & 3.2 & 3.2 \\
\hline 0.14 & 84.6 & 89.9 & 83.7 & 4.6 & 3.4 & 4.5 \\
\hline 0.20 & 85.5 & 91.5 & 83.7 & 5.4 & 4.3 & 4.5 \\
\hline
\end{tabular}

Table 2 Results of room A

\begin{tabular}{|c||ccc|ccc|}
\hline \multicolumn{1}{|c||}{} & \multicolumn{3}{c|}{ detected peak ratio [\%] } & \multicolumn{3}{c|}{ direction error[deg] } \\
\hline$R_{t h}$ & female & male & both & female & male & both \\
\hline \hline 0.03 & 37.1 & 36.9 & 34.2 & 5.2 & 5.0 & 5.3 \\
\hline 0.09 & 57.4 & 58.4 & 56.8 & 6.1 & 6.7 & 6.8 \\
\hline 0.14 & 70.2 & 74.7 & 69.3 & 9.8 & 7.9 & 8.9 \\
\hline 0.20 & 76.4 & 79.8 & 75.8 & 11.8 & 10.5 & 12.1 \\
\hline
\end{tabular}

均值を示す .ここで音源の持つ周波数を，元の音源のパワース ペクトルの最大值に対し $-6[\mathrm{~dB}]$ 以上のスペクトルを持つ周波 数と定義して適合ピークの割合を計算した .

各部屋の結果を Table 1, 2 にまとめる $R_{t h}$ の値を大きく するほど適合するピーク数が増加する一方で, 抽出されたピー ク方向の音源からの誤差も大きくなっている . 值は環境ごとに 異なるか誤差と検出率とはトレードオフの関係になっており，目 的や環境に応じて $R_{t h}$ を調整する必要がある. 本稿では, 部屋 $\mathrm{A}$ にて 7 [deg] 以下の誤差となる $R_{t h}=0.09$ を採用した .これ 以降 4,5 章の実験すべてに対して同じ值を用いる.千涉によっ て歪んだ空間スペクトルのピークは反射によるピークと比較し てモデルに近い傾向があり，例えば $R_{t h}=0.2$ とすると, 4.2 節 Fig. 8 (b) に示す干渉を受け $10[\mathrm{deg}]$ 程度ずれたピークはモ デルに適合と判定される.

4.2MLF による適合/不適合ピークの例

異なる条件下でMLF を行い, 適合ピーク/不適合ピークの 例を示す . 実験は, 部屋 $\mathrm{A}$ および残響時間 $\left(R T_{20}\right) 200[\mathrm{~ms}]$ ， 騷音レベル $\left(L_{A}\right) 44[\mathrm{~dB}]$ の部屋 B の 2 箇所で行った .

部屋 $\mathrm{A}$ にて二つのスピーカから $1[\mathrm{kHz}]$ のサイン波を出力し た場合の異なる時刻での $1[\mathrm{kHz}]$ の空間スペクトルを Fig. 8 に

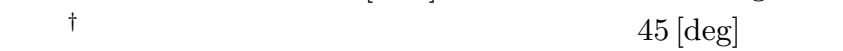
$180[\mathrm{deg}]$ 方向，距離はいずれも $2.0[\mathrm{~m}]$ である .グラフは，観 測された $1[\mathrm{kHz}]$ の空間スペクトル (実線) と推定されたメイン ローブモデル (点線) および観測スペクトルからモデルを減算 したスペクトル (破線) を表している.Fig.8 (a) は，44 [deg] および 180 [deg] に二つの音源を検出した例である . Fig. 8 (b) は , 188 [deg] の第一ピークに対して MLF でモデルと適合せず 除外された例である .Fig. 8 (b)では観測されたスペクトルはモ デルより細くなっており，190 [deg] から $250[\mathrm{deg}]$ にかけて差 が表れている. 複数の音源が同一周波数成分を持つ場合，干渉 によって音源方向以外にピークが発生することがあるが，MLF によって干渉を受けた成分を除外できることが分かる．

次に, MLF の結果, メインローブモデルと適合せず除外さ

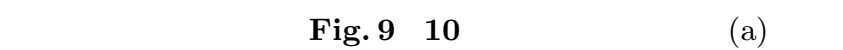
源配置，(b)に空間スペクトルを示している.音源はいずれも 1 [kHz] のサイン波とした . Fig. 9 は , 音源同士の間融を 45 [deg] とした場合の $1[\mathrm{kHz}]$ の空間スペクトルである . 160〜200 [deg]

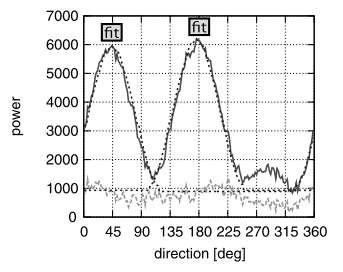

(a) Detect 2 peaks

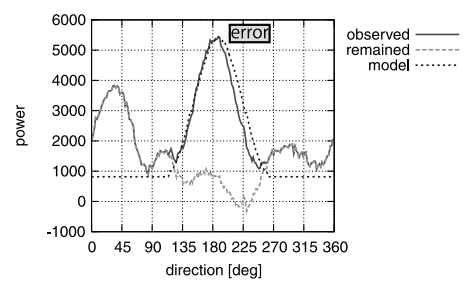

(b) Fitting error
Fig. 8 Examples of MLF on $1[\mathrm{kHz}]$ spatial spectrum

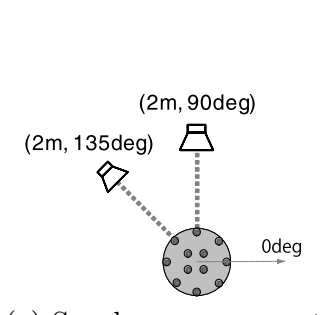

(a) Speaker arrangement

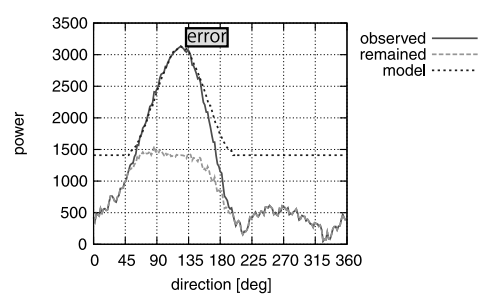

(b) Spatial spectrum
Fig. 9 Example of rejected peak by MLF: wrong peak between close two peaks

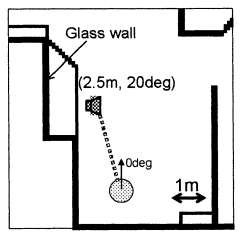

(a) Speaker arrangement

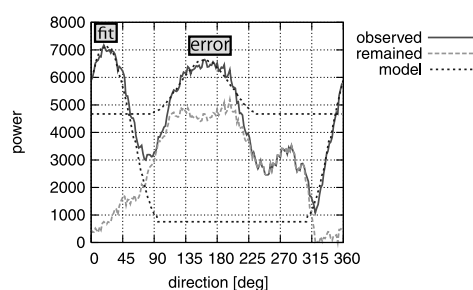

(b) Spatial spectrum
Fig. 10 Example of MLF rejected peak: reflection from a wall

にかけてモデルとの差が表れており，また推定された他音源か らの漏洩と背景雑音の和 (式 (5) の $P_{0}-S_{0}$ ) か対象ピーク 外の観測值より大きく，対象音源成分の推定値 (式 (5) の $S_{0}$ ) が不適切であることを示している．ビームフォーミングではメ インローブ幅が広いため，近接音源間に偽ピークが生じている が, 124 [deg] 方向に観測された第一ピークは , メインローブ幅 に対して音源間隔が狭いために生じた偽ピークであるが，モデ ルには適合せず MLF で除外された例である（観測可能な最小 音源間隔は，周波数ごとに異なる) .

Fig. 10 は反射により生じたピークの例である. 実験は部屋 B にて行った · 音源は $(2.5[\mathrm{~m}], 20[\mathrm{deg}])$ の位置にあり，ロボッ トの後ろ (180 [deg] 方向) には, 距離 $1.5[\mathrm{~m}]$ の位置に壁があ る.Fig. 10 (b) に示した MLF の結果では，18 [deg] に観測さ れた第一ピークをモデルに適合するピークとして検出している 一方で, $162[\mathrm{deg}]$ 方向に生じた第 2 ピークはメインローブの両 端 $(90 \sim 120 ， 200 \sim 230[\mathrm{deg}])$ でモデルと観測值との差が大き く，モデルに適合せず除外されている．ビームフォーミングで はメインローブ幅が広いため, 反射波が音源と比較して十分小 さな音圧であっても広範囲の重ね合わせによって大きく観測さ れ得るが MLF で除外でき，高反射，残響下において MLF が

\footnotetext{
${ }^{\dagger}$ モデルと観測值とのずれを分かりやすく示すため，モデルは式 (5) の $\left(P_{\theta_{n}}-S_{n}\right)$ 分加算した值を表示した .Fig. 9,10 についても同樣であ る。
} 

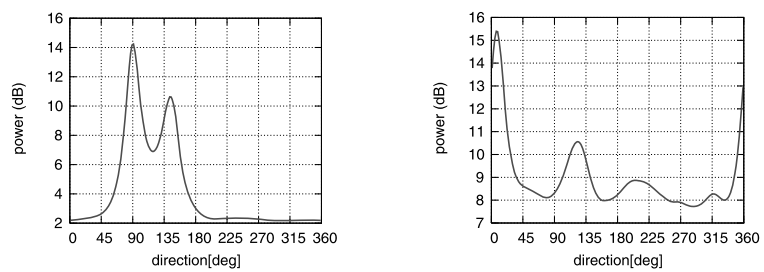

$\begin{array}{ll}\text { (a) MUSIC spectrum of Fig. } 9 & \text { (b) MUSIC spectrum of Fig. } 10\end{array}$

Fig. 11 MUSIC spectrums for rejected signal on MLF

有効であることが分かる .

Fig. 11 は, MLF で除外した Fig. 9,10 と同じ時刻の MUSIC スペクトルを示している . MUSICでは急峻なピークが得ら れるため，Fig. 9 の実験と同一条件で行った Fig. 11 (a)では二 つのピークを検出できており, 近接した音源に対しては DSBF より優位であることが分かる . Fig. 10 の実験と同一条件で行っ た Fig. 11 (b) では 20 [deg] 方向の音源以外にも 132 [deg] に第 2 ピークがあり，DSBF 同樣，反射の影響を受けている．

\subsection{MLF によるピーク検出評価}

次に, MLF の定量評価を行うために, 周波数の異なるサイン 波を合成した音源を用意し，音源に用いた周波数成分に対して MLF の評価を行った .なお音源には連続音を使用し，音が発生 していない区間はない . 評価には以下の二つの指標を用いる .

- 適合ピークの検出率 : 定位計算回数に対する, 真值との誤差 $\pm 10[\mathrm{deg}]$ 以内で検出された適合ピークの割合 . 音源から 届く信号のうちどの程度の割合が歪みの少ない成分として MLF で検出されるかを示す．

- 抽出ピークに含まれる誤検出率 : 検出されたピーク総数に対 する, 音源位置の真値 $\pm 10[\mathrm{deg}]$ 以外の方角に検出された ピークの割合 . 音源定位精度に与える影響を示す . 1 回の 定位ごとにMLF で複数回ピーク検出を繰り返し，検出さ れたピークの総和から定位を行うため, 適合ピークとして 検出されたピーク数に対する割合を指標とした .

$100 \%$ から適合ピークの検出率を引いた值が , 音源で発生してい ても MLF て検出できない割合を示す . また $100 \%$ から抽出ピー クに含まれる誤検出率を引いた值が , 抽出ピークのうち正しく 検出されたピークの割合を示す . 母数が異なるため適合ピーク の検出率と抽出ピークに含まれる誤検出率の和は 100[\%] では ない。

音源に用いる混合サイン波の周波数は，倍音の影響を避ける ため倍数とならない任意の 9 種とし，また周波数帯域による違 いを確認するため扱う周波数帯域全体に分布する組み合わせを 選んだ. 実験は，同一周波数成分を持つ二つの音源を $(2.2[\mathrm{~m}]$ ， $45[\mathrm{deg}]),(2.0[\mathrm{~m}], 180[\mathrm{deg}])$ においたものと, 弚れ独立 な周波数成分を持つ三つの音源を $(5.0[\mathrm{~m}], 30[\mathrm{deg}]),(2.2[\mathrm{~m}]$ ， $45[\mathrm{deg}]) ，(2.0[\mathrm{~m}], 180[\mathrm{deg}])$ においた場合の 2 種類である .

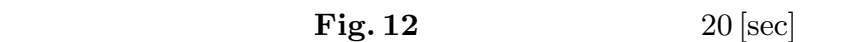
入力 $(20 / 0.128=156$ 回の計算) に対して評価を行った . 各音

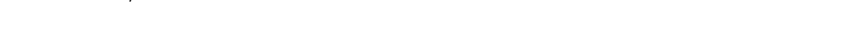
Table 3，4 にまとめる . 括弧内は抽出ピークに含まれる誤検 出率を示す.

Table 3 では二つの音源が同一周波数成分を持つため, Table

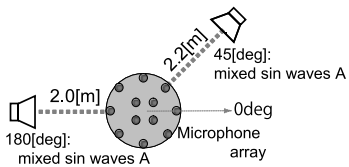

(a) Same 2 sounds

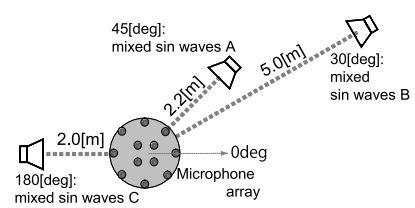

(b) Independent 3 sounds
Fig. 12 Speaker arrangement

Table 3 MLF result for same 2 sound sources

\begin{tabular}{c|cc||cc}
\hline \hline speaker position & \multicolumn{2}{|c||}{$(2.2[\mathrm{~m}], 45[\mathrm{deg}])$} & $(2.0[\mathrm{~m}], 180[\mathrm{deg}])$ \\
\hline & freq. & detect[\%] & freq. & detect[\%] \\
& {$[\mathrm{Hz}]$} & $($ error [\%] & {$[\mathrm{Hz}]$} & $($ error [\%]) \\
\cline { 2 - 5 } & 800 & $10.1(0.0)$ & 800 & $1.3(0.0)$ \\
& 1000 & $39.2(0.0)$ & 1000 & $41.8(0.0)$ \\
& 1300 & $87.3(0.0)$ & 1300 & $94.9(0.0)$ \\
& 1700 & $12.7(16.5)$ & 1700 & $46.8(16.5)$ \\
& 1900 & $77.2(0.0)$ & 1900 & $82.3(0.0)$ \\
& 2100 & $75.9(0.0)$ & 2100 & $7.6(0.0)$ \\
& 2350 & $83.5(0.0)$ & 2350 & $32.9(0.0)$ \\
& 2570 & $20.3(0.0)$ & 2570 & $50.6(0.0)$ \\
& 2800 & $3.8(0.0)$ & 2800 & $34.2(0.0)$ \\
\hline
\end{tabular}

Table 4 MLF result for independent 3 sound sources

\begin{tabular}{lc||cc||cc}
\hline \hline \multicolumn{2}{l||}{ speaker $(2.2[\mathrm{~m}], 45[\mathrm{deg}])$} & $(5.0[\mathrm{~m}], 30[\mathrm{deg}])$ & \multicolumn{2}{|c|}{$(2.0[\mathrm{~m}], 180[\mathrm{deg}])$} \\
\hline freq. & detect $[\%]$ & freq. & detect $[\%]$ & freq. & detect $[\%]$ \\
{$[\mathrm{Hz}]$} & $($ error $[\%])$ & {$[\mathrm{Hz}]$} & $($ error $[\%])$ & {$[\mathrm{Hz}]$} & $($ error $[\%])$ \\
\hline 800 & $13.9(0.0)$ & 910 & $1.3(13.9)$ & 850 & $88.6(0.0)$ \\
1000 & $0.0(0.0)$ & 1220 & $74.7(0.0)$ & 1090 & $100.0(0.0)$ \\
1300 & $100.0(0.0)$ & 1550 & $1.3(0.0)$ & 1410 & $97.5(0.0)$ \\
1700 & $48.1(0.0)$ & 1770 & $100.0(0.0)$ & 1630 & $67.1(0.0)$ \\
1900 & $100.0(0.0)$ & 2030 & $40.5(0.0)$ & 1860 & $100.0(0.0)$ \\
2100 & $82.3(0.0)$ & 2220 & $92.4(0.0)$ & 1970 & $97.5(0.0)$ \\
2350 & $72.2(0.0)$ & 2410 & $100.0(0.0)$ & 2160 & $96.2(0.0)$ \\
2570 & $70.9(0.0)$ & 2690 & $59.5(0.0)$ & 2290 & $74.7(0.0)$ \\
2800 & $64.6(0.0)$ & 2880 & $51.9(0.0)$ & 2500 & $100.0(0.0)$ \\
\hline
\end{tabular}

4 と比較して全体的に適合ピークの検出率が低くなっている . 抽 出ピークに含まれる誤検出率は $1,700[\mathrm{~Hz}]$ を除いて $0 \%$ であり， 干渉等の影響を除外できているといえる $1,700[\mathrm{~Hz}]$ について は $58 \sim 64[\mathrm{deg}]$ 方向に抽出ピークに含まれる誤検出が 9 回あつ た. 音源の持つ周波数成分が非常に少ないため $1,700[\mathrm{~Hz}]$ だけ 特異的に見えるが, 同一条件では近い周波数成分は似た傾向に なると考えられる. Table 4 では, 1 列目の $1,700[\mathrm{~Hz}]$ と 3 列 目の $1,630[\mathrm{~Hz}]$ など音源同士が近い周波数成分をもつ場合や，1 列目の $1,000[\mathrm{~Hz}]$ と 2 列目の $910[\mathrm{~Hz}]$ のように近接した 2 音源 の低周波数成分では適合ピークの検出率が低くなっている．ま た周波数ごとに適合ピークの検出率が変動しているが, 周波数 帯域や二つの実験の間に相関はない，本実験では位置を固定し 定常波を音源としたため, 兰れ周波数成分が受ける干渉 等の影響も定常となり，適合ピークの検出率の差として表れて いると考えられる .

\section{4 音源定位基礎実験}

4.3 節の 2 種類の条件についての音源定位結果を FBS , MUSIC による結果と合わせて Table 5,6 にまとめる.これ以 降，音源定位の評価では，無音区間を除き発生した音源を誤差 $\pm 10[\mathrm{deg}]$ 以内で定位できた割合として検出率を用いる．MLF について，個々の周波数ではモデルに適合するピークは少ない 
Table 5 Total localization result for same 2 sources

\begin{tabular}{c||c|c}
\hline \hline \multicolumn{1}{c||}{} & $(2.2[\mathrm{~m}], 45[\mathrm{deg}])$ & $(2.0[\mathrm{~m}], 180[\mathrm{deg}])$ \\
\cline { 2 - 3 } MLF & \multicolumn{2}{c}{ ave. direction[deg] } \\
\cline { 2 - 3 } FBS & 39.9 & 173.9 \\
MUSIC & 43.2 & 177.9 \\
\hline \multirow{3}{*}{ MLF } & 42.0 & 178.0 \\
\cline { 2 - 3 } FBS & \multicolumn{2}{c}{ correct detection [\%] } \\
MUSIC & 94.9 & 100.0 \\
\hline
\end{tabular}

Table 6 Total localization result for independent 3 sources

\begin{tabular}{c||c|c|c}
\hline \hline \multicolumn{1}{c||}{} & $(2.2[\mathrm{~m}], 45[\mathrm{deg}])$ & $(5.0[\mathrm{~m}], 30[\mathrm{deg}])$ & $(2.0[\mathrm{~m}], 180[\mathrm{deg}])$ \\
\hline \multirow{3}{*}{ MLF } & 41.6 & 30.3 & 177.6 \\
FBS & 41.8 & 32.5 & 177.6 \\
MUSIC & 42.0 & 31.4 & 177.1 \\
\hline \multirow{3}{*}{ MLF } & \multicolumn{3}{|c}{ correct detection [\%] } \\
\cline { 2 - 4 } FBS & 100.0 & 100.0 & 100.0 \\
MUSIC & 94.9 & 37.2 & 100.0 \\
\hline
\end{tabular}

一方で, 800〜3,000 [Hz] 全体から検出されたピーク群による音 源定位の結果は, どちらの実験も $100 \%$ に近い検出率となってい る . MLF で信頼度の高いピークのみを抽出することで, DSBF ベースの手法でも近接した音源や同一周波数成分を持つ音源を 定位可能であることが分かる.ただし同一周波数の 2 音源のよ うに抽出されるピークが少ない場合は定位角度誤差が大きい傾 向がある.FBSについては, 同一周波数の音源に対して片方の 検出率が低く, 音源同士の周波数か独立であっても近接した音 源に対する正答率が低い，MUSIC については，同一周波数の 2 音源をどちらも $100 \%$ 検出でき角度誤差も最も小さいが, 近 接した 2 音源で距離差が大きい場合の検出率が極端に低い .

\section{5. 音源定位実験}

距離差のある音源に対する定位精度 , および移動中のロボット からの音源定位実験について述べる . 前章同樣 , 1 回の定位計算 に用いるデータ長は 2,048 点 $(128[\mathrm{~ms}])$ とし , 800〜 3,000 [Hz] でバンドパスフィルタをかけた信号を用いる．また手法比較に 用いた MUSIC およびFBS の計算条件も前章と同樣である．

\section{1 距離変化に対する精度評価}

ロボット, 音源共に静止した状態で, 音源までの距離を変化さ せて音源定位の評価を行った . 実験環境は, 前章の部屋 A で行っ た . 音源には, あらかじめ接話マイクて録音した男声および女 声の発話を用い , スピーカから再生した . 男声音源を 135 [deg] 方向，距離 $1.5[\mathrm{~m}]$ に固定し，女声音源を 90 [deg] 方向，距離 1 ， $3,5,10[\mathrm{~m}]$ の 4 箇所に変化させた . 15 秒間の録音に対し, 検 出率および平均誤差を求めた . Fig. 13 に音源の配置图を示す.

Fig. 14 に 二つの音源光れの検出率を示す.Fig. 14 (a)， (b) とも横軸は距離を变化させた女声音源からマイクアレイまで の距離を表す . 比較のために MUSIC, FBSによる結果も合わ せて示す . MUSIC については, アレイの外周 8ch の入力によ る計算も行った。両音源とも, MLF, MUSIC, FBS , MUSIC (8ch) の順で検出率が低下している . Fig. 14 (a) の女声音源に

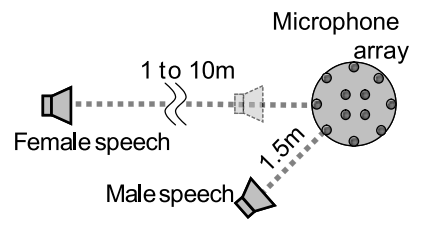

Fig. 13 Speaker arrangement for distant source localization

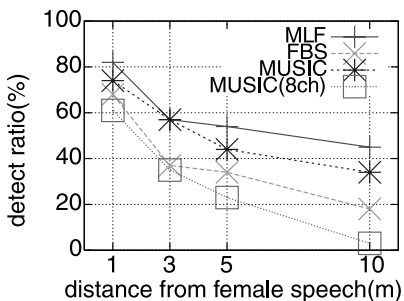

(a) Female speech

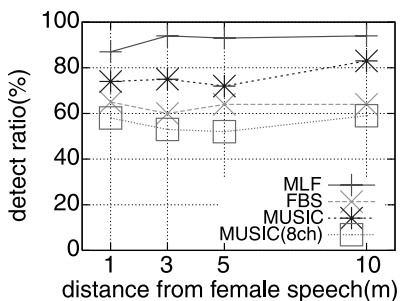

(b) Male speech
Fig. 14 Evaluation for distant sound source

ついて MLF を MUSIC と比較すると，3[m] 以下ではほとん ど差はないが, 距離 $10[\mathrm{~m}]$ では, $10 \%$ 差が生じている.ベース が同じビームフォーミングである FBS に対しては, 距離差が 大きくなるほど検出率に差か現れており，MLF で信頼度の高 いピークのみを抽出することで音源間の音圧差に頑健になって いることが分かる . 外周 8ch による MUSIC では, 距離 $3[\mathrm{~m}]$ 以下では, 32ch アレイによる FBS と変わらない検出性能が得 られているが, 距離 $5[\mathrm{~m}]$ 以上では急激に検出率が低下してお り，MUSIC が近距離では有効である一方，距離差の拡大に弱 いことが分かる . Fig. 14 (b) に示した距離 $1.5[\mathrm{~m}]$ に固定した 男声音源については, 他方の女声音源の距離か増加するにつれ て , どの手法も検出率がやや増加しているが , 大きな差はない .

\section{2 移動中のロボットによる音源定位}

移動中のロボットによる音源定位実験を行った . 音源にはあ らかじめ接話マイクで録音した男女五人の発話を用いた . $5 \mathrm{ch}$ DVD Audio (44[kHz] $16[\mathrm{bit}]$ サンプリング) を作成し，ス ピーカから再生した . 録音データの冒頭には解析時に真值との 同期を取るために $100[\mathrm{~ms}]$ の $2.5[\mathrm{kHz}]$ サイン波を挿入してお り，検出率の計算では発話と発話の間に生じる無音区間を除い ている . ロボットの操作はジョイスティックによる手動操作とし た . また音源方向の真値を得るために，モーションキャプチャ システム (MOCAP) を用いてロボットの軌跡を記録した . 用 いたシステムは MotionAnalysis の Eagle 10 台で , $5 \times 5[\mathrm{~m}]$ の範囲を計測可能である. Fig. 15 に実験環境の写真を示す． 残響時間 $\left(R T_{20}\right) 170[\mathrm{~ms}]$ ，騒音レベル $\left(L_{A}\right) 50[\mathrm{~dB}]$ である. Fig. 15 (b) は 5 音源の実験における音源位置およびロボットの 軌跡である. 実験は音源数を 1 〜 と変化させて計 5 回行い, 光 れ光れ $40[\mathrm{sec}]$ 間ロボットを走行させながら音源定位を行った . 各実験の音源位置は Fig. 15 (b) の音源 $\mathrm{A} \sim \mathrm{E}$ を A のみから昇 順に増加させた .

音源数 1〜 個に対する兰れ光れの実験結果をFig. 16 にま とめる . FBS は 2 音源以下では高い検出率を示しているが音源 の増加に伴い検出率が低下している . また音源方向以外の誤検 出が多い. MUSIC と MLF を比較すると, 検出率は MLF がや や良い值を示しており音源数増加とともに差か現れている. 誤 


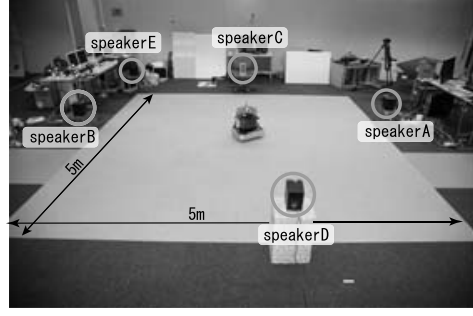

(a) Experimental setup

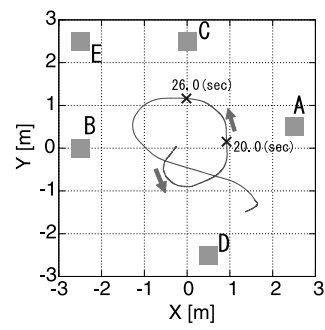

(b) Robot path
Fig. 15 Robot path and speaker arrangement

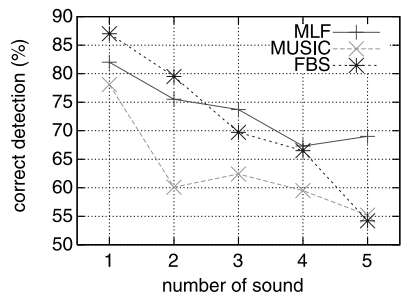

(a) Correct detection rate

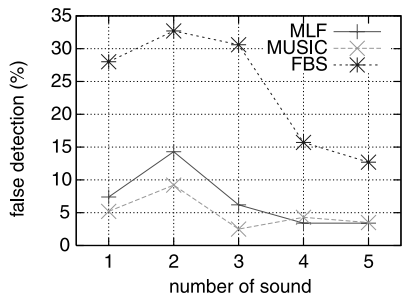

(b) False detection rate
Fig. 16 Evaluation results of sound localization while moving

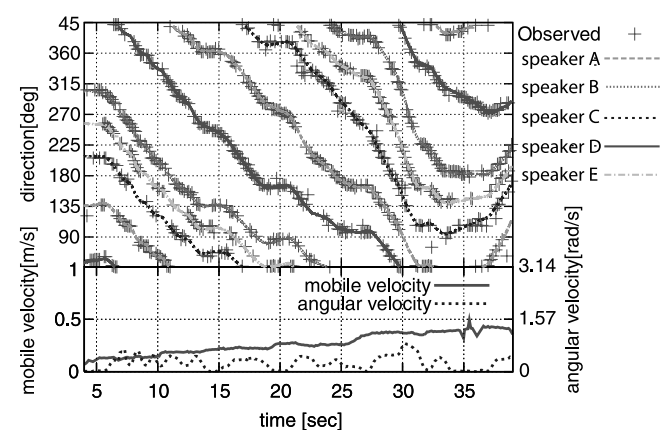

Fig. 17 MLF result while robot moving for 5 sources

検出率は 3 音源以下では MUSIC が最も低い . 音源数を既知と する MUSIC では実際の数以上の音源を同時定位することがほ とんどないのに対し, FBS , MLF では音源数より多い数を定 位することがあるためと考えられる . FBS と比較すると MLF の誤検出率は小さく，MLF の適用によって FBS で問題となっ ていた反射や干渉等による誤検出を除外できているといえる．

5 音源に対する MLF , FBS , MUSIC による音源定位結果を Fig. 17〜19 に示す. MOCAP で計測したロボットの移動軌跡 から計算した音源方向の真值を 5 種類の線に, 各手法で定位し た音源方向を十字で示している．FBSでは反射や雑音による誤 検出が多いことが分かる.特に Fig. 18 における 10 [sec] 前後の 音源 C , E 間 (135 [deg] 付近) など, 音源同士の間隔が 30 [deg] 以下になると真値との誤差が大きい . また MUSICでは, 誤検 出はほとんどなく精度よく定位できている．MUSIC を MLF と比較すると, $10[\mathrm{sec}]$ 前後の音源 Bや, $25[\mathrm{sec}]$ 前後の音源 D など，音源間の距離差がある際に遠い音源の検出率が低くなる 傾向があり，これが検出率差の原因と考えられる．20〜26 [sec] の音源 D 付近の拡大图を Fig. 20 に示す . 上段はスピーカ D か ら出力した音声 (同期信号を基にロボットに届いた時刻を算出)

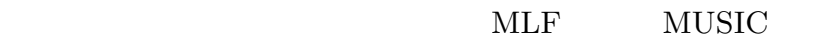

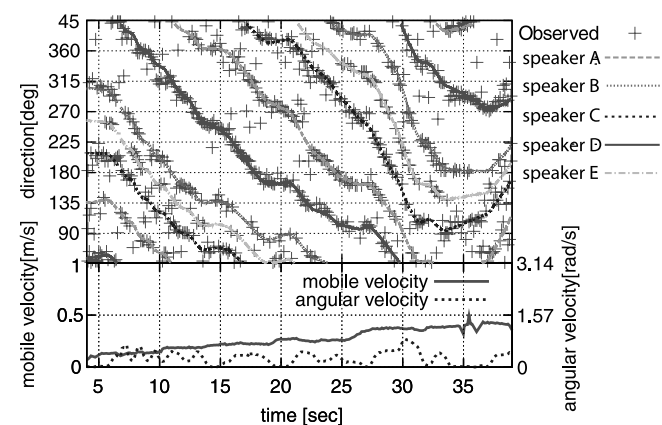

Fig. 18 FBS result while robot moving for 5 sources

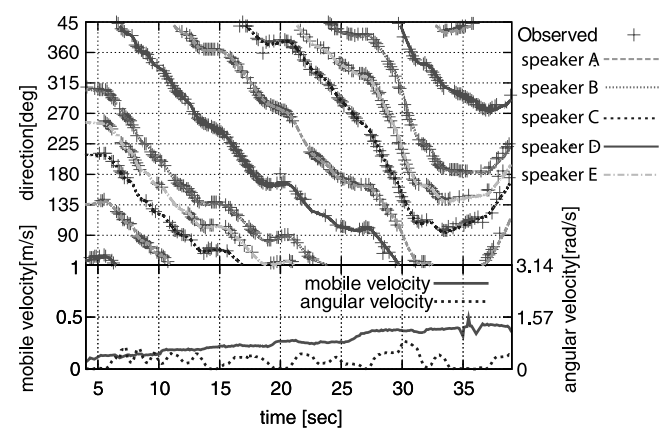

Fig. 19 MUSIC result while robot moving for 5 sources

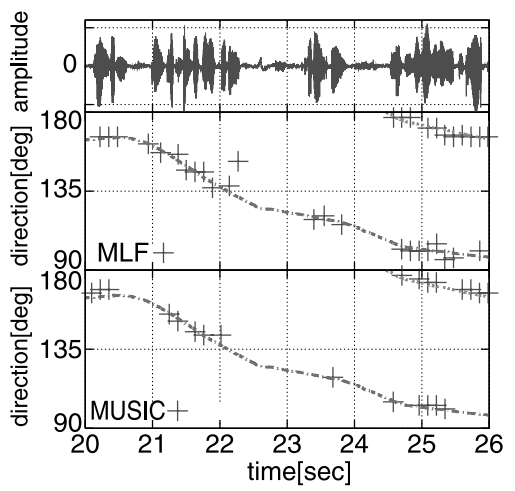

Fig. 20 Closeup of Fig. 17, 19 : comparison between MLF and MUSIC for speaker D

る定位結果を示す .この区間で音源 D を定位した回数は MLF が 24 回, MUSIC が 13 回と MUSIC の検出率が MLF に比べ 低いことが分かる . Fig. 15 (b) に時刻 20,26 [sec] のロボット 位置を $\times$ で示す。

ただし，32ch 入力に対する MUSIC は実時間処理をするには 計算量が多く, 実装のためには素子数を減らす, 計算周期に合 わせてデータを離散的に使うなどの工夫が必要である .

\section{6. おわりに}

本稿では, DSBF 時のメインローブモデルを用いた環境変化 に頑健な点音源検出手法を提案した . 提案手法により, 点音源 からの直接音と反射や干渉の影響を受けた周波数成分を判別す ることで, 反射, 干渉のある環境下での弱い点音源の定位を実 現している. DSBF 時のメインローブモデルを用いて点音源を 検出し，反射や他音源からの干渉を受けた周波数成分を除くこ 
とで, 環境変化に対する音源定位性能の劣化を防ぐことが可能 である. 4 章の実験結果より, 音源数や残響時間の異なる環境で も，検出したピークの角度誤差に大きな差はなく，シミュレー ションから求めたメインローブモデルが信頼度の高いピークを 検出するのに有効であることが分かる . また移動ロボットによ る音源定位実験から，提案手法は FBSや MUSIC と比較して， 近接した複数音源や音源までの距離差の拡大に対して有効性が 高いといえる.

提案手法は, 反射や干渉の有無を判断し, 信頼度の高い成分 のみを定位計算に用いるというアプローチである．とのため， 特により高残響の環境下では, 自身の音の反射成分によって多 くの成分が除外され，検出率が低下することが考えられる．反 射, 回折等の影響を考慮したビームモデルを持つことで, 部屋 の角からの回り込み等, ロボットから直接見えない音の検出が 可能であると考えられる . 回折音のモデル等, 点音源モデル以 外のモデルへの MLF の適用が今後の課題である .

\section{参 考 文 献}

[1 ] J.-M. Valin: "Auditory System for a Mobile Robot," PhD thesis, Sherbrooke University, 2005.

[2] I. Hara, F. Asano, H. Asoh, J. Ogata, N. Ichimura, Y. Kawai, F. Kanehiro, H. Hirukawa and K. Yamamoto: "Robust speech interface based on audio and video infomation fusion for humanoid HRP-2," Proceedings of 2004 IEEE/RSJ International Conference on Intelligent Robot and Systems (IROS2004), pp.2404-2410, 2004.

[ 3 ] M. Sato, A. Sugiyama and S. Ohnaka: "Near-field sound-source localization and adaptive noise cancellation in a personal robot, papero," Proceedings of the 22th Meeting of Special Interest Group on AI Challenges, pp.41-46, 2005.

[4] 廣川潤子, 古賀敏之, 鈴木薰, 小川秀樹, 松日楽信人：“高性能聴覚 機能を持つ聞き分けロボットの開発”, 日本機械学会ロボティクス・ メカトロニクス部門講演論文集, pp.1A1-E16, 2006.

[5] D.H. Johnson and D.E. Dugeon: Array Signal Processing: Concepts and Techniques. Prentice Hall, 1993.

[6] 加賀美聡, 佐々木洋子 : “移動ロボットからの複数音源の定位と分離の ためのマイクアレイ評価”，計測と制御，vol.46, no.6, pp.453-459, 2007.

[ 7 ] F. Asano, M. Goto, K. Itou and H. Asoh: "Real-time sound source localization and separation system and its application to automatic speech recognition,"Proceedings of European
Conference on Speech Communication and Technology (Eurospeech2001), pp.1013-1016, 2001.

[8] 村瀬昌澫, 中臺一博, 奥乃博 : “パーティクルフィルタによる音源追 跡の性能評価”, 情報処理学会第 68 回全国大会予稿集, pp.5M-9, 2006.

[9] S. Argentieri and P. Danes: "Broadband variations of the music high-resolution method for sound localization in robotics," Proceedings of IEEE/RSJ International Conference on Intelligent Robots and Systems (IROS-2007), pp.2009-2014, 2007.

[10] J.-M. Valin, F. Michaud and J. Rouat: "Robust localization and tracking of simultaneous moving sound sources using beamforming and particle filtering," Robotics and Autonomous Systems Journal, vol.55, pp.216-228, 2007.

[11] E. Martinson and A. Xchultz: "Auditory evidence grids," Proceedings of 2006 IEEE/RSJ International Conference on Intelligent Robot and Systems (IROS2006), pp.1140-1145, 2006.

[12] H.-D. Kim, J.-S. Choi and M. Kim: "Speaker localization among multi-faces in noisy environment by audio-visual integration," Proceedings of IEEE-RAS International Conference on Robots and Automation (ICRA2006), pp.1305-1310, 2006.

[13] H. Asoh, I. Hara and F. Asano: "Tracking human speech events using a particle filter," Proceedings of IEEE International Conference on Acoustics, Speech, Signal Processing (ICASSP 2005), pp.MSP-P2.6, 2005.

[14] K. Nakadai, H. Nakajima, M. Murase, S. Kaijiri, K. Yamada, Y. Hasegawa, H. Tsujino and H.G. Okuno: "Real-time tracking of multiple sound sources by integration of in-room and robotembedded microphone arrays," Proceedings of IEEE/RSJ International Conference on Intelligent Robots and Systems (IROS-2006), pp.852-859, 2006.

[15] Y. Sasaki, S. Kagami and H. Mizoguchi: "Multiple sound source mapping for a mobile robot by self-motion triangulation," Proceedings of 2006 IEEE/RSJ International Conference on Intelligent Robots and Systems (IROS2006), pp.380-385, 2006.

[16] L.J. Griffiths and C.W. Jim: "An alternative approach to linearly constrained adaptive beamforming," IEEE Transactions on Antennas and Propagation, vol.30, no.1, pp.27-34, 1984.

[17] 中島弘史 : “ミニマックス規範に基づくサイドローブ最小ビームフォー ミング”, 日本音響学会誌, vol.63, no.7, pp.341-352, 2007.

[18] R.A. Kennedy and T.D. Abhayapala: "Nearfield beamforming using radial reciprocity," IEEE Trans. on Signal Processing, vol.47, pp.33-40, 1999.

[19] 佐々木洋子, 加賀美聡, 溝口博 : “移動ロボット搭載用 $32 \mathrm{ch}$ マイク ロホンアレイの設計と精度評価”, 第 24 回日本ロボット学会学術講 演会予稿集 CD-ROM , 1B19, 2006.

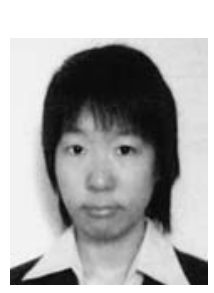

佐々木洋子( Yoko Sasaki)

2007 年東京理科大学大学院理工学研究科機械工学 専攻修士課程修了. 同年, 同大学同研究科同専攻博 士課程進学.同年, 日本学術振興会特別研究員. 現 在に至る. 日本機械学会の会員 .

(日本ロボット学会学生会員)

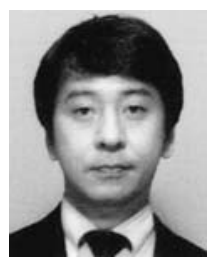

溝口 博 ( Hiroshi Mizoguchi)

1985 年東京大学大学院工学系研究科情報工学専攻 博士課程修了. 同年株式会社東芝総合研究所 (現 : 研究開発センター) 入所. 1994 年東京大学先端科 学技術研究センター，1996 年文部省短期在外研究 員 (ケンブリッジ大学) , 1997 年埼玉大学工学部情 報システム工学科教授を経て, 2002 年東京理科大 学理工学部機械工学科教授. 2003 年産業技術研究所デジタルヒューマ ン研究センター客員研究員. 情報処理学会, 計測自動制御学会, IEEE の会員 .

(日本ロボット学会正会員)

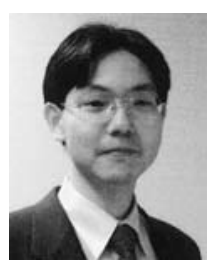

加賀美聡 ( Satoshi Kagami)

1997 年東京大学大学院工学系研究科情報工学専攻 博士課程修了. 博士 (工学). 同年より日本学術振 興会未来開拓学術研究推進事業「マイクロ・ソフト メカニクス統合体としての高度生体機能機械の研 究」プロジェクトにより東京大学リサーチアソシ エート. 2001 年産業技術総合研究所入所 . デジタル ヒューマン研究ラボの主任研究員 . 2003 年改組によりデジタルヒュー マン研究センター・ヒューマノイドインタラクションチームのチーム 長.

(日本ロボット学会正会員) 